ELWIRA LITASZEWSKA

Uniwersytet im. Adama Mickiewicza

w Poznaniu

\title{
NIEETATOWE ROZWIĄZANIE KARIEROWE JAKO SPOSÓB GROMADZENIA KAPITAŁU KARIERY
}

\begin{abstract}
Litaszewska Elwira, Nieetatowe rozwiazanie karierowe jako sposób gromadzenia kapitału kariery [Part-Time Career Solution as a Way to Accumulate Career Capital]. Studia Edukacyjne nr 43, 2017, Poznań 2017, pp. 283-294. Adam Mickiewicz University Press. ISSN 1233-6688. DOI: 10.14746/se.2017.43.17

The structure of the study was subordinate to the question about the characteristics of career choices undertaken in the discourse of lifelong learning and career planning. The distinguishing mechanisms for selected career development approaches emphasize the importance of entrepreneurial attitudes and the effective use of personal resources. The accumulation of career capital can be a response to the demands of the modern labor market and to the dynamics of the changes taking place within it. This approach is quite strongly focused on non-career career choices, exemplified by start-ups.
\end{abstract}

Key words: career, career development, competence development, lifelong learning, start-up

\section{Wybory karierowe - wokół problematyki skutecznego funkcjonowania na rynku pracy}

Wzorce przebiegu współczesnych karier oraz moment podejmowania, trwałych czy też tymczasowych, aktywności zawodowych ulegają przeobrażeniom, jednak nietrudno zgodzić się ze słowami, iż nadal „większość absolwentów charakteryzuje swoista cezura między terminem zakończenia nauki a podjęciem pracy, która sprawia, że ich napływ na rynek pracy dokonuje się stopniowo i ma charakter sezonowy"1. Powyższe stwierdzenie

${ }^{1}$ K. Mlonek, Bezrobocie w Polsce w XX wieku w świetle badań, Warszawa 1999, s. 132. 
pozostaje nadal szczególnie symptomatyczne dla studentów $\mathrm{w}$ stacjonarnym trybie studiów, który dla pracodawców niesie często komunikat równoznaczny z obawami dotyczącymi dyspozycyjności potencjalnego pracownika. Liczba osób gotowych do podjęcia pełnej aktywności na rynku pracy wzrasta z chwilą odebrania dyplomu, czyli symbolicznym etapem zakończenia pewnego etapu kształcenia. Dla niektórych przedstawicieli młodzieży akademickiej może być to nadal debiut $\mathrm{w}$ pracowniczej roli zgodnej z kierunkiem kształcenia, również wobec wcześniej podejmowanych praktyk, staży, programów ambasadorskich czy też wolontariatu.

Praca zawodowa stanowi niejednokrotnie ostateczną odpowiedź na zróżnicowane ludzkie potrzeby. Determinuje samoocenę oraz wpływa na usytuowanie osób w grupach społecznych. Staje się osią zaangażowania, źródłem satysfakcji oraz nośnikiem prestiżu. Czasami obdarza stereotypami bądź, wręcz przeciwnie, daje szansę na ich dezaktualizację. W oczywisty sposób pozostawanie bez pracy jest stanem niepożądanym dla wszystkich, w tym dla studentów oraz absolwentów, dla których ważna jest samorealizacja - najczęściej utożsamiana z możliwością pełnego wykorzystywania kompetencji. Nie bez znaczenia pozostaje również, a być może staje się dominujący, czynnik finansowy.

Konfrontacja absolwentów z sytuacją panującą na rynku pracy może skutecznie ochłodzić ich zawodowe ambicje. Jest to szczególnie rozpoznawalne wówczas, kiedy okazuje się, iż liczba osób chętnych do podjęcia zatrudnienia rzadko bywa adekwatna do aktualnych potrzeb pracodawców. Oprócz tego ma miejsce rotacja pracowników z doświadczeniem zawodowym, którzy mogą czuć się w uprzywilejowanej pozycji wobec pozostałych uczestników rynku pracy, w szczególności tych debiutujących.

W przypadku wielu osób może ujawnić się realny i trudny do natychmiastowego rozwiązania problem ze skutecznym wejściem i utrzymaniem się na rynku pracy. Nasilone oraz wkraczające wciąż do obszaru jednostkowych aspiracji zainteresowanie edukacją na poziomie wyższym nie wskazuje na kryzys zaufania w procesie odbioru usług dydaktycznych na najwyższych poziomach kształcenia. Zróżnicowane i nie zawsze pomyślne prognozy w zatrudnieniu zdają się nie hamować edukacyjnego entuzjazmu. Jednak zintensyfikowane możliwości edukacyjne w zakresie uzyskiwania dyplomu uczelni wyższej mogą potęgować coraz większe ograniczenia oraz zawodowe rozczarowania $\mathrm{w}$ perspektywie indywidualnych doświadczeń. Dyplom niejednokrotnie uzyskuje status dokumentu o dyskusyjnej wartości w ręku absolwenta. Potencjalni pracodawcy wciąż determinują kształt struktury 
zatrudnienia, decydując się również na podnoszenie selekcyjnej poprzeczki coraz wyżej.

Zbyszko Melosik stwierdza, iż

w społeczeństwie neoliberalnym jednostka, która poszukuje sensu istnienia zdaje się być "bez sensu”. Rynek pracy i bezduszne instytucje oraz biurokracja są ślepe na problemy egzystencjalne i ze swoim "metafizycznym przeznaczeniem”. Osoba, która ma takie problemy jest mało wydajna - zawodowo i tożsamościowo. Sprawia bowiem problemy sobie i innym. Sens życia jest współcześnie podawany ludziom w dwóch typach pakietów. Pierwszy pakiet sensu życia wynika z jego rekonstrukcji wokół konsumpcji i wolności konsumpcyjno-kulturowych wyborów; drugi jest zdecydowanie zorientowany na karierę zawodową oraz osobistą. Jasno więc widać, że tożsamość neoliberalnej jednostki ma być całkowicie wydrenowana z problemów egzystencjalnych, które zastępowane są frustracjami z powodu niepowodzeń w życiu zawodowym lub osobistym bądź niemożliwości spektakularnego uczestnictwa w społeczeństwie konsumpcji².

Na uwagę zasługuje również występowanie „kultury frustracji”. Uczestnicy tej kultury doznają krzywd i niezadowolenia na skutek dominującej potrzeby osiągania wyższego poziomu życia oraz dóbr materialnych, które na podstawie doświadczeń innych jawią się jako możliwe do osiągnięcia, jednak nie przez nich samych ${ }^{3}$.

Nieustanne zwiększanie wysiłku, zaangażowania i rosnący poziom zwątpienia ze strony poszukujących pracy lub podejmujących zatrudnienie, jak również ich zróżnicowane edukacyjne wybory, podejmowane $\mathrm{w}$ celu znalezienia się $\mathrm{w}$ optymalnej sytuacji zawodowej, staje się niemal regułą. Ewa Solarczyk-Ambrozik pisze na ten temat:

edukacyjne drogi dorosłych, wiodące przez społeczne i zawodowe struktury, w społeczeństwie informacyjnym podporządkowane są w coraz wyższym stopniu wymaganiom rynkowym ${ }^{4}$.

Okoliczności pozbawiające stabilizacji stymulują działania studentów i absolwentów, a także osób już doświadczonych zawodowo, którzy zaczynają szukać wsparcia na każdym etapie zawodowej biografii.

Konieczność zmiany zawodu, przekwalifikowania się, zmiany miejsca pracy czy okresowe bezrobocie uzależnione są od kondycji gospodarki oraz tworzą zbiór przykładowych sytuacji postrzeganych jako duża zmiana,

2 Z. Melosik, Neurotyczna tożsamość w społeczeństwie neoliberalnym, Studia Edukacyjne, 2015, 37, s. 82.

${ }^{3}$ E. Nowicka, Świat człowieka - świat kultury, Warszawa 2009, s. 428.

${ }^{4}$ E. Solarczyk-Ambrozik, Ksztatcenie ustawiczne w perspektywie globalnej i lokalnej. Między wymogami rynku pracy a indywidualnymi strategiami edukacyjnymi, Poznań 2009, s. 35. 
a także wymagających zwiększonego wysiłku. Przeszkody pojawiające się na drodze aktywności zawodowej stawiają niejednokrotnie trudny do odrzucenia wymóg szukania pomocy wśród specjalistów.

Wiele osób mogłoby wskazać pewne sfery zawodowego funkcjonowania obarczone deficytami i wymagające usprawnienia. W wielu przypadkach własna aktywność osób, u których występuje trudność, nie przynosi zamierzonych efektów, dlatego rozwiązaniem może okazać się zewnętrzne wsparcie wyspecjalizowanej osoby. Doradca zawodowy zwykle nie funkcjonuje odrębnie, lecz przynależy do konkretnej placówki, w ramach której oferuje swoją działalność. Pomoc najczęściej przyjmuje postać instytucjonalnej formy doradztwa i odbywa się w ramach świadczenia usług przez Biura Karier, Urzędy Pracy, czy też Inkubatory Przedsiębiorczości. Działania doradcze, dzięki utrzymywaniu wysokich standardów pracy, stają się z jednej strony trwałe i kompleksowe, natomiast $\mathrm{z}$ drugiej - dostosowane do indywidualnych potrzeb osób radzących się.

Okoliczności, w których aspiracje zawodowe nie są możliwe do zrealizowania w ojczystym kraju, przesądzają o decyzjach dotyczących zarobkowego wyjazdu do innego państwa. Praca za granicą pozostaje czasami odosobnioną szansą na podjęcie zatrudnienia, zwłaszcza wówczas, kiedy w rodzinnym kraju pojawiają się problemy ze zdobyciem stałego źródła dochodu. Otwarcie rynku pracy, regulowane unijnie, spowodowało masowe migracje ludności. Jeżeli emigrują osoby o wysokich, często specjalistycznych kwalifikacjach, mamy do czynienia ze zjawiskiem określanym wcześniej jako drenaż mózgów. W takim rozumieniu właśnie wtedy ojczysty kraj traci największy zawodowy potencjał. Drenaż mózgów to sformułowanie, które utrwalając się w licznych dyskusjach, nabierało coraz bardziej negatywnego wydźwięku. Obecnie jest utożsamiane ze skutkami globalizacji oraz łączone $\mathrm{z}$ naturalnymi procesami społeczno-ekonomicznymi, dzięki czemu traci na, nacechowanym szczególnie pejoratywnie, znaczeniu. Obecnie można spotkać się z odmiennymi nazwami, mianowicie cyrkulacja lub wymiana mózgów 5 .

Uzupełniając to, co zostało dotychczas przedstawione, warto zwrócić uwagę na "nadwyżkę wykształcenia” (overeducation). Termin ten nadaje nazwę dla okoliczności, w których absolwenci szkół wyższych podejmują

${ }^{5}$ P. Kaczmarczyk, J. Tyrowicz, Migracje osób z wysokimi kwalifikacjami, Biuletyn nr 3, Fundacja Inicjatyw Społeczno-Ekonomicznych, Warszawa 2008, s. 7; http://rynekpracy. org/files/1bezrobocie.org.pl/public/biuletyny_fise/biuletyn_fise_nr4_kwalifikowani.pdf [dostęp: 12.03.2017]. 
pracę $\mathrm{w}$ zawodach poniżej poziomu ich kwalifikacji ${ }^{6}$. Na nadwyżkę wykształcenia można spojrzeć uwzględniając kilka kierunków interpretacji, mianowicie: jako problem strukturalny (konsekwencja faktu, iż popyt na rynku pracy nie odpowiada podaży, występują ograniczenia $\mathrm{w}$ liczbie miejsc pracy związanych z określonymi kwalifikacjami), stan przejściowy (intencjonalne działanie absolwentów ukierunkowane na przygotowanie się do realizacji kolejnego etapu kariery zawodowej; czas przeznaczony na zdobycie doświadczeń oraz podporządkowany indywidualnej strategii rozwoju), czy też problem pozorny (koncentracja na znaczeniu pozaedukacyjnych czynników w skuteczności odnajdywania zatrudnienia oraz weryfikacyjny charakter mechanizmów rynku pracy) ${ }^{7}$.

Poszukiwanie podobieństw w sytuacji absolwentów szkół wyższych (opuszczających edukacyjne struktury) oraz sytuacji osób przymusowo pozostawiających miejsca pracy (zwalnianych) dostarcza szerszego kontekstu poznawczego dla wątków podejmowanych w niniejszym opracowaniu. Zadanie, któremu musi sprostać każda wyróżniona grupa jest tożsame, jest nim zdobycie zatrudnienia (wejście $w$ nowe organizacyjne schematy). W tym przypadku podstawową ramą kategorialną staje się proces, osadzony dotychczas zdecydowanie $\mathrm{w}$ doradztwie personalnym, określany jako "outplacement" 8 . Takiemu założeniu towarzyszy rozpoznanie wspólnego mianownika dla programu monitorowanych zwolnień grupowych (outplacement) oraz programu poradnictwa dla studentów i absolwentów (instytucjonalne doradztwo zawodowe realizowane przede wszystkim przez wyspecjalizowane jednostki uczelniane - Biura Karier).

Istotę programu outplacement $\mathrm{w}$ bardzo obrazowy sposób oddają inne określające go nazwy, mianowicie: system łagodnych zwolnień, program kompleksowej pomocy zwalnianym, przygotowanie pracownika do życia $\mathrm{w}$ zmianie, wsparcie pracownika i pracodawcy $\mathrm{w}$ procesie restrukturyzacji, kultura zwalniania pracowników, monitorowana redukcja zatrudnienia9 ${ }^{9}$ Realizacja standardu charakterystycznego dla programu outplacement sta-

${ }^{6}$ A. Kiersztyn, Nadwyżka wykształcenia na polskim rynku pracy. Młodzi w zawodach poniżej kwalifikacji, [w:] Polityka edukacyjna wobec rynku pracy, red. D. Kotlorz, A. Rączaszek, Katowice 2012, s. 77.

7 Tamże, s. 78.

8 J. Minta, Doradcy uczelnianych Biur Karier jako realizatorzy programu „outplacement" dla społeczności akademickiej, Edukacja Ustawiczna Dorosłych, 2003, 3(42), s. 94-104.

${ }_{9}^{9}$ B. Piotrowski, Outplacement - podstawowy pakiet informacji, Fundacja Inicjatyw Społeczno-Ekonomicznych, Warszawa 2010, s. 4;

http://rynekpracy.org/files/1bezrobocie.org.pl/public/broszury_outplacement_praca_w_po lsce/100304_BPiotrowski_broszura_outplacement_PUP.pdf, [dostęp: 12.03.2017]. 
nowi wyraz dbałości o osobę, która definitywnie opuszcza główne miejsce swojej dotychczasowej aktywności. Joanna Minta wskazuje, iż

osoby, które znajdują się poza dotychczasową strukturą, mają do wyboru dwie drogi: wytrwale szukać gotowej struktury, która je przyjmie, bądź samodzielnie tworzyć miejsca pracy. Jednakże, aby wchodzić w gotowe struktury i aby tworzyć nowe, należy posiadać pewne obycie na rynku pracy, które najogólniej wyraża się w umiejętności określenia swoich kwalifikacji, oczekiwań i możliwości zawodowych, umiejętności efektywnego i aktywnego poszukiwania pracy, umiejętności autoprezentacji, jak i wiedzy zarówno o lokalnym rynku pracy, jak i o zasadach prowadzenia własnej działalności, itp. ${ }^{10}$

Nową formułą, która umożliwi rozwój kariery zawodowej może stać się również startup. W tych okolicznościach rolę odpowiedzialnej struktury organizacyjnej, podejmując interpretację „przygotowania pracownika do życia w zmianie", mogą przyjąć Inkubatory Przedsiębiorczości, zwłaszcza te związane ze środowiskiem akademickim. Akademickie Inkubatory Przedsiębiorczości jako jednostka, która „umożliwia przetestowanie pomysłów na rynku na preferencyjnych warunkach i bez konieczności rejestracji działalności gospodarczej lub spółki"11, mogą stać się kolejnymi - obok Biur Karier - „realizatorami programu outplacement dla społeczności akademickiej”12. Warto również podkreślić, iż startup nie powstaje tylko w jednym celu utrzymywania produktu i usługi; aktywności połączonych z zarabianiem pieniędzy. Startup jest tworzony po to, aby „uczyć się sposobów budowy rentownej firmy"13. Można również uznać, iż jest prowadzony w celu gromadzenia kapitału kariery (akumulacji i rozwoju zasobów karierowych).

\section{Kapitał kariery - pomiędzy edukacją a aktywnością zawodową}

Agnieszka Cybal-Michalska pisze:

wielość, sfragmentaryzowanie, zmienność i złożoność form społecznej organizacji, ich wpływ na jakość kształtowania karier sprawia, iż zasadne wydaje się postawienie pytania o esencje procesu związanego z planowaniem perspektywy kariery oraz dookreślenie: czy i w jaki sposób jednostka może być przygotowana do „budowania”

10 J. Minta, Doradcy uczelnianych Biur Karier, s. 96.

11 https:/ / aip.org.pl, [dostęp: 12.03.2017].

12 J. Minta, Doradcy uczelnianych Biur Karier, s. 94-104.

13 E. Ries, Metoda Lean Startup, przekł. B. Sałbut, Gliwice 2012, s. 14. 
swojej kariery, gwarantującej jej satysfakcjonujące przeżywanie własnej osoby i swojego miejsca w rzeczywistości? ${ }^{14}$

Rekrutacyjne sukcesy, zakończone zdobyciem miejsca pracy, tworzą warunki dla realizowania kariery zawodowej, szczególnie tej przyporządkowanej określonej strukturze organizacyjnej. Trudno jednak zebrać wyczerpujący i jednoznaczny katalog wszystkich czynników, które determinują gwarantowaną zatrudnieniem skuteczność aplikacji na rynku pracy. Dodatkowo, liczba ofert pracy na jawnym oraz ukrytym rynku pracy jest rozmieszczona nieproporcjonalnie.

Indywidualne aktywności związane z ubieganiem się o pracę niejednokrotnie przyjmują postać długotrwałych i wymagających zaangażowania strategii radzenia sobie na rynku pracy. Celem procesu rekrutacyjnego (a dokładniej selekcyjnego) jest rozstrzygnięcie, w określonych ramach czasowych i organizacyjnych, o przydatności danego kandydata na określone stanowisko pracy oraz rozpoznanie obszaru deficytów jego kompetencji, które w całym swym kształcie mogą przesądzić o włączeniu tej osoby w struktury przedsiębiorstwa.

Zdobycie zatrudnienia, postrzegane jako skuteczna odpowiedź kandydata na wymagania pracodawcy, znajduje swój wyraz w dopasowaniu do trzech zawodowych płaszczyzn, czyli dostosowaniu kandydata do wybranego stanowiska pracy (person-job fit) oraz organizacji (person-organization fit), jak również do zespołu (person-team fit) ${ }^{15}$. Częstokroć jednak młodzi ludzie mają trudności ze zdefiniowaniem reguł rządzących aktywnością zawodową, przez co zaczynają doświadczać problemów z realizowaniem kariery zawodowej.

Magdalena Piorunek referując autorskie badania, wskazuje, iż wśród przedstawicieli młodzieży akademickiej można rozpoznać trzy sposoby pojmowania kariery ${ }^{16}$. Pierwszy z nich to kariera jako "społeczny awans". W tym przypadku dominuje ujęcie obiektywistyczne, ściśle związane ze wskaźnikami charakterystycznymi dla realizowania kariery. Kolejny to „konstrukt dualny niepodlegający ewaluacji”, o atrybutach społecznopersonalnych. Ostatni sposób utożsamia karierę z „personalną właściwością podmiotu". Cytowana autorka sygnalizuje również następujące interpretacje

14 A. Cybal-Michalska, Rozwój kariery jako proces inwestowania w kapitat kariery, Studia Edukacyjne, 2012, 22, s. 207.

${ }^{15}$ N. Anderson, N. Cunningham-Snell, Selekcja pracowników, przekł. A. Tyszkiewicz, [w:] Psychologia pracy i organizacji, red. N. Chmiel, Gdańsk 2002, s. 84.

${ }_{16}$ M. Piorunek, Kariera wedtug młodych, czyli nowy paradygmat kariery na dysonansowym rynku pracy, Studia Edukacyjne, 2016, 38, s. 87-90. 
studentów w sferze dotyczącej kariery, które różnicują się ze względu na możliwe do uchwycenia klucze skojarzeń. Mianowicie17: „określenia o neutralnym charakterze deskryptywnym” (także fizykalne), "personalny wymiar kariery", "gratyfikacje związane z realizacją kariery”, "negatywne skutki przebiegu karier zawodowych" oraz „właściwości i kompetencje skojarzone z konstruowaniem indywidualnej ścieżki kariery". Zróżnicowane skojarzenia oddają złożony charakter procesu społecznego, którym jest w percepcji młodzieży akademickiej - realizacja kariery zawodowej.

Eskalujący wymóg działań skoncentrowanych na wspieraniu alokacji indywidualnych zasobów na rynku pracy wytycza obszar dyskusji nad budowaniem kapitału kariery. Kapitał kariery to „zakumulowane kompetencje, które jednostka uzyskuje w toku edukacji, pracy, doświadczenia życiowego, doświadczenia społecznego oraz kulturowego"18. „Kapitał” nie jest terminem zwyczajowo stosowanym $w$ naukach o edukacji. Warto jednak w tym miejscu podkreślić to, o czym mówił Edmund S. Phelps - amerykański noblista, laureat $\mathrm{w}$ dziedzinie ekonomii, mianowicie: „ekonomia nie jest nauką o zarabianiu pieniędzy. To jest nauka o relacjach między gospodarką a życiem społecznym" 19 .

Augustyn Bańka wskazuje na następujące rodzaje kapitału²0:

- finansowy (jako „pieniądze przeznaczone do inwestowania”),

- fizyczny (czyli „realne dobra: sprzęt lub infrastruktura”),

- ludzki (jako „poziom kwalifikacji determinujący wydajność pracy”),

- kulturowy (czyli „wiedza kulturowa, której posiadacz może użyć do podwyższenia swojego statusu społeczno-ekonomicznego"),

- społeczny (jako „więzi zaufania zawarte w strukturze społecznych powiązań"),

- edukacyjny („wartość rynkowa jednostki wyceniana na podstawie udokumentowanych kompetencji edukacyjnych"),

- reputacji („wycena wartości rynkowej jednostki na podstawie marki”),

- personalny („rynkowa atrakcyjność jednostki w autoprezentacji społecznej"),

17 Tamże, s. 90.

18 A. Bańka, Kapitał kariery - uwarunkowania, rozwój i adaptacja do zmian organizacyjnych oraz strukturalnych rynku pracy, [w:] Wspótczesna psychologia pracy i organizacji, red. Z. Ratajczak, A. Bańka, E. Turska, Katowice 2006, s. 90.

19 E.S. Phelps, Rynek $w$ cuglach, rozm. przepr. Jacek Żakowski, Polityka Cyfrowa, 2008; http://www.polityka.pl/tygodnikpolityka/spoleczenstwo/270751,1,rozmowa-z-noblistaedmundem-phelpsem.read, [dostęp: 12.03.2017].

${ }^{20}$ A. Bańka, Kapitat kariery - uwarunkowania, rozwój i adaptacja, s. 81. 
- doświadczenia („zakumulowane doświadczenia życiowe jako transsytuacyjne dobra umożliwiające zwiększanie skuteczności działania"),

- kariery ("podmiotowa postrzegana wartość zasobów personalnych umożliwiających ustanawianie oraz podtrzymywanie zdolności zatrudnieniowej jednostki").

Niewątpliwie, nadal największe dyskusje prowadzone są na temat kapitału społecznego. O jego potencjale decyduje „uprzywilejowanie w dostępie do informacji" 21 oraz edyfikacja opierająca się na sile przekazu rekomendacji. Wśród debat o sieci kontaktów i docieraniu do korzystnych dla rozwoju kariery zawodowej komunikatów utrwalił się również termin "alfabetyzm sieciowy” jako "zdolność do opanowania, pozyskania i wykorzystania informacji przepływających w obrębie sieci kontaktów" 22 .

\section{Prowadzenie startupu - wskazówki dla konstruowania karier zawodowych}

Propozycja karierowego rozwiązania pod hasłem „jesteś startupem" rekomenduje "myślenie o sobie jak o przedsiębiorcy odpowiedzialnym za przynajmniej jedno rozwijające się od zera przedsięwzięcie" - mianowicie za własną karierę zawodową ${ }^{23}$. Nie jest to współcześnie podejście odosobnione, ponieważ postawa przedsiębiorcza niesie ogromny ładunek praktyczny. Przedsiębiorczość jest często identyfikowana jako próba odpowiedzi na wyzwania teraźniejszości oraz utożsamiana z obietnicą skutecznego funkcjonowania $\mathrm{w}$ zawodowej przyszłości. Pojawia się ona $\mathrm{w}$ dyskursie dotyczącym nowego ładu dydaktycznego i organizacyjnego na różnych poziomach kształcenia oraz w rozmaitych instytucjach. Jednak rozwiązanie karierowe, znamienne dla prowadzenia startupów, stanowi dosyć nietradycyjną formułę w praktyce doradczej, chociaż sama idea startupu już od kilku lat stanowi synonim przedsiębiorczości, kreatywności, innowacyjności.

Startup to „tymczasowa organizacja zajmująca się poszukiwaniem skalowalnego, powtarzalnego i rentownego modelu biznesowego", jednak nie stanowi małego wydania dużej firmy ${ }^{24}$. Inny autor podaje, iż startup oznacza „ludzką instytucję stworzoną z myślą o budowaniu nowych produktów

${ }^{21}$ Tamże, s. 85.

${ }^{22}$ R. Hoffman, B. Casnocha, Jesteś start-upem. Buduj swoja przyszłość, inwestuj w siebie i realizuj się zawodowo, przekł. B. Sałbut, Gliwice 2014, s. 209.

${ }^{23}$ Tamże, s. 14.

24 S. Blank, B. Dorf, Podręcznik startupu - budowa wielkiej firmy krok po kroku, przekł. B. Sałbut, Gliwice 2013, s. 19. 
lub usług w warunkach skrajnej niepewności"25. Na uwagę zasługuje również fakt, iż można spotkać się z rekomendacjami dotyczącymi uczenia się korporacji od startupów ${ }^{26}$. Jest to stanowisko niewątpliwie związane z kształtowaniem przedsiębiorczości korporacyjnej, rozumianej jako działania przedsiębiorcze zachodzące $\mathrm{w}$ środku organizacji ${ }^{27}$. Jej synonimy to intraprzedsiębiorczość, intrakorporacyjna przedsiębiorczość, wewnętrzna przedsiębiorczość korporacyjna, tworzenie przedsiębiorczej strategii, postawa przedsiębiorcza na poziomie firmy, orientacja przedsiębiorcza, innowacyjna przedsiębiorczość, korporacyjne przedsięwzięcia ${ }^{28}$.

Przedsiębiorczość to zdecydowany atrybut procesów gospodarczych oraz społecznych. Jeden z podziałów wyróżnia przedsiębiorczość międzynarodową, przedsiębiorczość w sektorze organizacji społecznych (non-profit), przedsiębiorczość w administracji rządowej i lokalnej, przedsiębiorczość gospodarczych systemów zorganizowanych, przedsiębiorczość małego biznesu oraz przedsiębiorczość własną ${ }^{29}$. Rozważania podjęte $\mathrm{w}$ niniejszym opracowaniu koncentrują się wokół dwóch ostatnich rodzajów, czyli przedsiębiorczości własnej oraz małego biznesu.

Reid Hoffman i Ben Casnocha wskazują, iż indywidualne podejście przedsiębiorcze, wzorowane na naturalnym funkcjonowaniu startupów w permanentnej zmianie, koncentruje się wokół rozwoju bardzo sprecyzowanych umiejętności. Należą do nich: budowanie przewagi konkurencyjnej (opartej na indywidualnych aspiracjach i zasobach oraz rzeczywistość rynkową), planowanie zakładające dostosowywanie się (elastyczność, adaptacyjność), budowanie sieci kontaktów zawodowych oraz przekształcanie ich w autentyczne relacje (sojusze zawodowe jako wymiana zasobów, nie transakcje), korzystanie z przełomowych okazji (odnajdywanie lub ich samodzielne konstruowanie), podejmowanie świadomego ryzyka (inteligentne ryzyko) oraz wydobywanie informacji z sieci kontaktów ${ }^{30}$.

${ }^{25}$ E. Ries, Metoda Lean Startup, przekł. B. Sałbut, Gliwice 2012, s. 28.

${ }^{26}$ K. Królak-Wyszyńska, Czas na odchudzanie, czyli czego korporacje moga uczyć się od startupów; dostęp: http://innovatika.pl/2016/08/16/czas-na-odchudzanie-czyli-czego-korporacjemoga-uczyc-sie-od-startupow, [dostęp: 12.03.2017].

${ }_{27}$ G. Głód, Przedsiębiorczość publiczna w kontekście zarzadzania zmianą w jednostkach ochrony zdrowia, [w:] Determinanty potencjatu rozwoju organizacji, red. A. Stabryła, K. Woźniak, Kraków 2012, s. 115.

28 Tamże.

29 J.D. Antoszkiewicz, Rozwijanie przedsiębiorczości - wybrane koncepcje, [w:] Przedsiębiorczość: szansa na sukces rządu, gospodarki, przedsiębiorstw, społeczeństwa, red. K. Piech, M. Kulikowski, Warszawa 2003, s. 13-14.

${ }^{30}$ R. Hoffman, B. Casnocha, Jesteś start-upem, s. 32-229. 
Wskazówki, sformułowane na kształt ogólnych zasad, dotyczące podnoszenia skuteczności osobistej, które związane są z funkcjonowaniem startupów, mają pełne uzasadnienie na gruncie całożyciowego doradztwa kariery. Szczególnie istotne jest to, iż wskazane rozwiązanie karierowe ilustruje „proces wymuszający na przyszłym pracowniku przejęcie odpowiedzialności za własny rozwój", czyli jak podaje O. Bergstrom - eksternalizację zatrudnienia ${ }^{31}$.

Na gruncie powyższych analiz warto podkreślić, iż jak ujmuje to Ewa Solarczyk-Ambrozik:

większość koncepcji wyjaśniających fenomen wyborów karierowych zakłada, że pewne charakterystyki indywidualne i elementy środowiska stwarzają jednostkom możliwości doświadczeń związanych z uczeniem się. Edukacja karierowa staje się przewidywaną trajektorią zadań rozwojowych realizowanych poprzez kształtowanie umiejętności niezbędnych do rozwijania kariery w różnych organizacjach. Na problem relacji zachodzących między jej rozwojem a całożyciowym uczeniem się (lifelong learning - LLL) można spojrzeć zarówno od strony edukacji karierowej, jak i edukacji w trakcie przebiegu kariery ${ }^{32}$.

\section{BIBLIOGRAFIA}

Anderson N., Cunningham-Snell N., Selekcja pracowników, przekł. A. Tyszkiewicz [w:] Psychologia pracy i organizacji, red. N. Chmiel, Gdańskie Wydawnictwo Psychologiczne, Gdańsk 2002.

Antoszkiewicz J.D., Rozwijanie przedsiębiorczości - wybrane koncepcje, [w:] Przedsiębiorczość: szansa na sukces rzadu, gospodarki, przedsiębiorstw, społeczeństwa, red. K. Piech, M. Kulikowski, Instytut Wiedzy, Warszawa 2003.

Bańka A., Kapitat kariery - uwarunkowania, rozwój i adaptacja do zmian organizacyjnych oraz strukturalnych rynku pracy, [w:] Wspótczesna psychologia pracy i organizacji, red. Z. Ratajczak, A. Bańka, E. Turska, Wydawnictwo Uniwersytetu Śląskiego, Katowice 2006.

Blank S., Dorf B., Podręcznik startupu - budowa wielkiej firmy krok po kroku, przekł. B. Sałbut, Wydawnictwo Helion, Gliwice 2013.

Cybal-Michalska A., Rozwój kariery jako proces inwestowania w kapitał kariery, Studia Edukacyjne, 2012, 22.

Głód G., Przedsiębiorczość publiczna w kontekście zarzadzania zmiana w jednostkach ochrony zdrowia, [w:] Determinanty potencjału rozwoju organizacji, red. A. Stabryła, K. Woźniak, Mfiles.pl, seria wydawnicza: Encyklopedia Zarządzania, Kraków 2012.

31 G. Plencer-Borecka, A. Gawron, Ł. Borecki, Udział kompetencji społecznych i działań transgresyjnych $w$ kształtowaniu kapitału kariery, [w:] Problemy edukacji wobec rozwoju społecznogospodarczego. Studia Ekonomiczne 131, red. A. Rączaszek, W. Koczur, Katowice 2013, s. 140.

32 E. Solarczyk-Ambrozik, Zmiany we wzorach przebiegu karier a całożyciowe uczenie się, [w:] Doradztwo zawodowe w perspektywie całożyciowego uczenia się, red. E. Solarczyk-Ambrozik, Poznań 2016, s. 41. 
Hoffman R., Casnocha B., Jesteś start-upem. Buduj swoja przyszłość, inwestuj w siebie i realizuj się zawodowo, przekł. B. Sałbut, Wydawnictwo Helion, Gliwice 2014.

Kiersztyn A., Nadwyżka wykształcenia na polskim rynku pracy. Młodzi w zawodach poniżej kwalifikacji, [w:] Polityka edukacyjna wobec rynku pracy, red. D. Kotlorz, A. Rączaszek, Wydawnictwo Uniwersytetu Ekonomicznego w Katowicach, Katowice 2012.

Melosik Z., Neurotyczna tożsamość w społeczeństwie neoliberalnym, Studia Edukacyjne, 2015, 37.

Minta J., Doradcy uczelnianych Biur Karier jako realizatorzy programu "outplacement" dla społeczności akademickiej, „Edukacja Ustawiczna Dorosłych”, Instytut Technologii Eksploatacji, Radom, 2003, 3(42).

Mlonek K., Bezrobocie w Polsce w XX wieku w świetle badań, Krajowy Urząd Pracy, Warszawa 1999.

Nowicka E., Świat człowieka - świat kultury, Wydawnictwo Naukowe PWN, Warszawa 2009.

Piorunek M., Kariera wedtug młodych, czyli nowy paradygmat kariery na dysonansowym rynku pracy, Studia Edukacyjne, 2016, 38.

Plencer-Borecka G., Gawron A., Borecki Ł., Udziat kompetencji społecznych i działań transgresyjnych w ksztattowaniu kapitatu kariery, [w:] Problemy edukacji wobec rozwoju społeczno-gospodarczego. Studia Ekonomiczne 131, red. A. Rączaszek, W. Koczur, Wydawnictwo Uniwersytetu Ekonomicznego w Katowicach, Katowice 2013.

Ries E., Metoda Lean Startup, przekł. B. Sałbut, Wydawnictwo OnePress, Gliwice 2012.

Solarczyk-Ambrozik E., Ksztatcenie ustawiczne w perspektywie globalnej i lokalnej. Między wymogami rynku pracy a indywidualnymi strategiami edukacyjnymi, Wydawnictwo Naukowe UAM, Poznań 2009.

Solarczyk-Ambrozik E., Zmiany we wzorach przebiegu karier a całożyciowe uczenie się, [w:] Doradztwo zawodowe w perspektywie całożyciowego uczenia się, red. E. SolarczykAmbrozik, Wydawnictwo Naukowe UAM, Poznań 2016.

\section{Źródła internetowe}

Kaczmarczyk P., Tyrowicz J., Migracje osób z wysokimi kwalifikacjami, Biuletyn nr 3, Fundacja Inicjatyw Społeczno-Ekonomicznych, Warszawa 2008, s. 7; http://rynekpracy. org/files/1bezrobocie.org.pl/public/biuletyny_fise/biuletyn_fise_nr4_kwalifikowa ni.pdf, [dostęp: 12.03.2017].

Królak-Wyszyńska K., Czas na odchudzanie czyli czego korporacje moga uczyć się od startupów; http:/ /innovatika.pl/2016/08/16/czas-na-odchudzanie-czyli-czego-korporacjemoga-uczyc-sie-od-startupow, [dostęp: 12.03.2017].

Phelps E.S., Rynek w cuglach, rozm. przepr. Jacek Żakowski, Polityka Cyfrowa, 2008; http://www.polityka.pl/tygodnikpolityka/spoleczenstwo/270751,1,rozmowa-znoblista-edmundem-phelpsem.read, [dostęp: 12.03.2017].

Piotrowski B., Outplacement - podstawowy pakiet informacji, Fundacja Inicjatyw SpołecznoEkonomicznych, Warszawa 2010, s. 4; http://rynekpracy.org/files/1bezrobocie. org.pl/public/broszury_outplacement_praca_w_polsce/100304_BPiotrowski_broszu ra_outplacement_PUP.pdf [dostęp: 12.03.2017]; https://aip.org.pl [dostęp: 12.03. 2017]. 